research on switching and transmission systems and techniques. Mr. White will be director of research in the physical sciences, including physics, chemistry, semiconductors, solid state electronics, metallurgy and materials. With Dr. J. R. Pierce, formerly director of research in electrical communications and now director of research in communications principles, Dr. Lewis and $\mathrm{Mr}$. White will report to Dr. W. O. Baker, vice-president in charge of research.

\section{Commonwea'th Co-operation in Scientific Research}

IN the course of a speech on October 20 when opening the Esso Research Laboratories at Abingdon, the Lord President of the Council, Viscount Hailsham, referred to our comparative neglect of research as a nation, to which we devoted far too little of our resources, and emphasized the role of industry and the universities as well as of the Government. He said that in the view of the Government it was most important that there should be available in the Commonwealth, for those members who needed it, advice and assistance from other members including the United Kingdom, wherever these were available and funds could be found to meet it. Accordingly, the Government had announced at Montreal that, under the general control of the Committee of the Privy Council, an Overseas Research Council would be set up concerned with scientific research overseas, particularly in the Commonwealth (Nature of November 22, p. 1413). Our existing organizations in industrial, medical, and agricultural science would be available to give assistance through this new body, and he hoped new and fruitful scientific links would be formed in this way between Great Britain and members of the Commonwealth. Secondly, Lord Hailsham welcomed the attention which the United States was giving to research in the tropics, and particularly in Africa, as a fruitful field for Anglo-American co-operation (Nature of November 8, p. 1276).

\section{The Institute for Strategic Studies, Ltd.}

THE formation of the Institute for Strategic Studies, Ltd., for the study of defence and disarmament has been announced. The Institute will be international, but the headquarters will be in London. Mr. Alastair Buchan, formerly defence and diplomatic correspondent and now assistant manager of the Observer, has been appointed director. The purpose of the Institute is to provide a focus for the study and discussion of the effects of political and scientific developments upon strategy, Western defence policies, and disarmament plans. It is also intended to develop a reference centre. The Ford Foundation in New York has made a grant of 150,000 dollars to finance the Institute for the first three years.

The founder members of the council of the Institute are : Sir Kenneth Grubb (chairman, Commission of the Churches on International Affairs) (chairman), Mr. Richard Goold-Adams (vice-chairman), Lord Salter (honorary treasurer), Prof. P. M. S. Blackett (professor of physics, Imperial College of Science and Technology), the Rev. Alan Booth (secretary, Commission of the Churches on International Affairs), Rear-Admiral Sir Anthony Buzzard (director, VickersArmstrongs, Ltd.), Air Chief Marshal Sir Ronald Ivelaw-Chapman, Lieutenant-General Sir John Eldridge, Mr. Kurt Hahn (former headmaster, Gordonstoun and Salem Schools), Captain B. H. Liddell Hart, Sir William Hayter (warden of New College, Oxford), Mr. Denis Healey, M.P., Mr.
Michael Howard (lecturer in war studies, King's College, London), Sir James Hutchison, M.P., Lord MeNair, Marshal of the R.A.F. Sir John Slessor, Sir Henry Tizard, Mr. Donald Tyerman (editor of the Economist), Canon H. M. Waddams (secretary, Church of England Council on Foreign Relations), Lord Weeks, and Mr. C. M. Woodhouse (directorgeneral, Royal Institute of International Affairs). The Institute will also have an international advisory committee on strategy, defence, and international affairs throughout the Free World.

\section{Committee of Public Accounts: Report for 1957-58}

IN its third report for the session 1957-58 (pp. 32 . London: H.M. Stationery Office, 1958. 1s. 6d. net) the Committee of Public Accounts admits that the evidence given to the Committee last session regarding the cost of construction of the Jodrell Bank radio telescope was gravely inaccurate and misleading. The accounting officer now states that he is satisfied, after discussing the matter with the University of Manchester, that there was extensive consultation between the consultant engineers and the professor in charge on questions of design. There was, in fact, the fullest collaboration on scientific and technical matters between the consultants and the professor, and accordingly the concern expressed by the Committee in its third report for the session $1956-57$ is essentially unfounded. It is, however, still not satisfied with the financial control exercised over this scheme, either by the Department or by the University, and weleomes the Treasury minute on its previous report indicating that steps are being taken to ensure close control by both the university and the Government department concerned in any future case of this kind. The Treasury has now authorized payment of an additional grant of $£ 130,000$, making a total of $£ 560,000$, and the Committee welcomes the assurance that the balance of the expenditure for the construction of the telescope will be found from other sources by the University (Nature, November 29, p. 1484).

\section{United States Euratom Agreement}

An agreement for co-operation in the civil uses of atomic energy between the United Statjs and Euratom was signed on November 8 in Brussels. The major objective of the agreement is to bring into operation in the Community in the next five to seven years approximately one million electrical kilowatts of nuclear power capacity, using reactor types developed in the United States. It is expected that the provisions for wide dissemination of information under the programme will provide industrial organizations in the Community and the United States with valuable engineering experience, and technological and economic data concerning the operation of nuclear power plants in Europe under conditions that will be nearly competitive with conventionally fuelled plants. The capital cost of the joint nuclear power programme, exclusive of fuel, is expected to be about $350,000,000$ dollars. An integral part of the programme is a joint ten-year research and development project. During the first five years the Community and the United States will each contribute up to $50,000,000$ dollars. Before the expiration of the first five years the participants will determine the financial requirements for the remaining five years and will undertake to procure the necessary funds for the programme. 